\title{
EXPLORE
}

\section{Penerapan Metode Technique For Others Reference By Similarity To Ideal Solution (Topsis) Dalam Pemilihan Tanaman Bonsai Terbaik}

\author{
Sri Ipnuwati, Kencana Aditama \\ Program Studi Sistem Informasi \\ STMIK Pringsewu Lampung \\ Lampung, Indonesia \\ nengachie@gmail.com,goldaditama@gmail.com
}

\begin{abstract}
Bonsai plants are made as miniature from the original shape of large trees that werw old in the wild, which can increase the value of art because of its unique shape, the intended artistic value is in the case of cutting, pruning and forming tree branches in accordance with the desired path. To determine the best bonsai plants, many people only determine the shape of the bonsai, in the fact the best bonsai plants are determined by specific criteria such as plant age, plant height, stem type, leaf condition, leaf size, and the number of leaves. With these problems, the authorb wants to make decision making system with the method "Technique for Others Reference by Similarity to Ideal Solution (TOPSIS)" to determine the best bonsai plants. From a number of alternatives used, this system produces a decision that the best value falsl on bonsai kemuning bonsai with a value of 0.756031 .
\end{abstract}

Keyword : Decision Support System, Bonsai, TOPSIS Method

\begin{abstract}
Abstrak-Tanaman bonsai dibuat sebagai miniatur dari bentuk asli pohon besar yang sudah tua dialam bebas, yang dapat meningkatkan nilai seni karna bentuknya yang unik, nilai seni yang dimaksud adalah dalam hal pemotongan, pemangkasan dan pembentukan cabang pohon sesuai dengan alur yang diinginkan. Untuk menentukan tanaman bonsai terbaik banyak maysarakat hanya menentukan dari bentuk bonsai-nya saja, sebenarnya tanaman bonsai yang terbaik ditentukan dengan kriteria tertentu seperti usia tanaman, tinggi tanaman, jenis batang, kondisi daun, ukuran daun, dan jumlah daun. Dengan adanya permasalahan tersebut penulis ingin membuat Sistem Pengambilan Keputusan dengan metode Technique for Others Reference by Similarity to Ideal Solution (TOPSIS) untuk menentukan tanaman bonsai terbaik. Dari sejumlah alternatif yang digunakan sistem ini menghasilkan keputusan bahwa nilai terbaik jatuh pada bonsai kemuning dengan nilai 0.756031 .
\end{abstract}

Kata Kunci : Sistem Pendukung Keputusan, Bonsai, Metode TOPSIS

\section{Pendahuluan}

Bonsai merupakan sebuah upaya seni untuk mengkerdilkan tanaman sebagai keindahan panorama alam yang penuh dengan beraneka ragam pepohonan, baik bentuk, jenis dan warnanya. Pada hakikatnya seni bonsai adalah meniru atau membuat tiruan dari bentuk tanaman yang ada di alam bebas yang tumbuhnya merana akibat keganasan alam. Seni bonsai di Indonesia berkembang cukup baik. Hal ini karena didukung oleh kesuburan alam dan kekayaan jenis flora tropis nya. Indonesia terdiri dari banyak pulau dan hampir di setiap pulau mempunyai jenis flora khusus yang menjadi ciri khasnya. Jenis-jenis flora khusus di Indonesia tersebut dapat menjadi bahan bonsai yang bagus. Dari bahanbahan inilah karya seni bonsai di Indonesia lahir.[1]

Proses pembentukan bonsai yang berlangsung terus menerus sepanjang hidup pohon tersebut, bonsai yang sempurna membutuhkan waktu yang relatif lama, kemudian membutuhkan kreativitas, kesabaran, ketekunan dan kecintaan pembuatnya terhadap tanaman. Bagi maysrakat yang ingin membudidayakan bonsai biasanya dalam menentukan tanaman bonsai hanya dilihat dari bentuknya saja namun sebenarnya tanaman bonsai yang terbaik ditentukan dengan kriteria tertentu seperti usia tanaman, tinggi tanaman, jenis batang, kondisi daun, ukuran daun, dan jumlah daun. Untuk membantu penentuan dalam menetapkan tanaman bonsai terbaik maka dibutuhkan sebuah sistem pendukung keputusan. Salah satu metode yang dapat digunakan untuk Sistem Pendukung Keputusan adalah dengan menggunakan metode Technique for Order Preference by Similarity to Ideal Solution (TOPSIS). 
Dengan adanya sistem informasi pemilihan tanaman bonsai terbaik berdasarkan penilaian metode Technique for Order Preference by Similarity to Ideal Solution (TOPSIS) ini akan membantu masyarakat dalam memilih tanaman bonsai terbaik secara ideal.

\section{Dasar Teori}

\section{A. Penelitian Serupa}

Penelitian yang dilakukan oleh Dwi Kurniawan dan Sri Ipnuwati (2018) dengan judul "Penggunaan Metode Topsis Menentukan Jenis Bambu Untuk Pembuatan Alat Rumah Tangga Tradisional". Dengan menggunakan lima (5) kriteria yaitu warna bambu, usia bambu, diameter bambu, panjang bambu, ketebalan bambu. Menggunakan empat (4) alternatif yaitu bambu tutul, bambu apus, bambu betung, dan bambu gombong. Dari perhitungan Topsis diperoleh hasil bahwa bambu gombong merupakan bambu pilihan untuk membuat alat rumah tangga tradisional dengan jumlah sesuai dengan kriteria yang sudah ditentukan [2].

Penelitian yang dilakukan oleh Eka Aprilia dan Sri Ipnuwati (2018) dengan judul "Sistem Pendukung Keputusan Pemilihan Wisata Air Terjun Unggulan Dengan Menggunakan Metode Topsis di Kabupaten Pesawaran”. Dengan menggunakan lima (5) kriteria yaitu view atau pemandangan, jarak, waktu tempuh, biaya masuk, fasilitas. Kemudian penelitian ini menggunakan lima (5) alternatif yaitu air terjun tanah longsor, air terjun kaliawi, air terjun sinar tiga, air terjun ciupang, dan air terjun hurun, metode Topsis dipilih karena mampu memilih alternatif terbaik dari sejumlah alternatif yang ada. Dari sejumlah alternatif yang ada yang menjadi alternatif terbaik adalah Air Terjun Tanah Longsor dengan nilai 0,6751. Air Terjun tanah longsor menjadi wisata air terjun unggulan dengan nilai tertinggi[3].

\section{B. Sistem Pendukung Keputusan (SPK)}

Sistem berasal dari bahasa Latin (systema) dan bahasa Yunani (sustema) adalah suatu kesatuan yang terdiri dari komponen atau elemen yang dihubungkan bersama untuk memudahkan aliran informasi, materi atau energi. Istilah ini sering dipergunakan untuk menggambarkan suatu set entitas yang berinteraksi, dimana suatu model matematika seringkali bisa dibuat.[3]

Menurut Turban dkk.. (2005), Sistem Pendukung Keputusan atau sering disebut Decision Support System (DSS) adalah Sistem berbasis model yang terdiri dari prosedur-prosedur dalam pemrosesan data dan pertimbangannya untuk membantu manajer dalam mengambil keputusan. Agar berhasil mencapai tujuannya maka sistem tersebut harus sederhana, robust, mudah untuk dikontrol, mudah beradaptasi lengkap pada hal-hal penting dan mudah berkomunikasi dengannya. Secara implisit juga berarti bahwa sistem ini harus berbasis komputer dan digunakan sebagai tambahan dari kemampuan penyelesaian masalah dari seseorang[4].

Menurut Kusrini (2007:15), SPK merupakan sistem Informasi Interaktif yang menyediakan informasi pemodelan, dan pemanipulasian data. Dari pendapat yang dikemukakan diatas dapat disimpulkan bahwa sistem pendukung keputusan adalah suatu sistem informasi berbasis komputer yang digunakan untuk membantu manajemen untuk mengambil keputusan[4].

\section{Technique for Others Reference by Similarity to Ideal Solution (TOPSIS)}

TOPSIS adalah salah satu metode pengambilan keputusan multi kriteria yang pertama kali diperkenalkan oleh Yoon dan Hwang (1981). TOPSIS menggunakan prinsip bahwa alternatif yang terpilih harus mempunyai jarak terdekat dari solusi ideal positif dan jarak terpanjang (terjauh) dari solusi ideal negatif dari sudut pandang geometris dengan menggunakan jarak Euclidean (jarak antara dua titik) untuk menentukan kedekatan relatif dari suatu alternatif dengan solusi optimal[3].

Secara umum prosedur TOPSIS mengikuti langkahlangkah sebagai berikut:

1. Menentukan matriks keputusan yang ternormallisasi.

2. Menghitung matriks keputusan yang ternormalisasi ter bobot.

3. Menghitung matriks solusi ideal positif dan matriks solusi ideal negatif.

4. Menghitung jarak antara nilai setiap alternative dengan matriks solusi ideal positif dan matriks solusi ideal negatif.

5. Menghitung nilai preferensi untuk setiap alternatif.

Adapun langkah-langkah dari metode TOPSIS ini sebagai berikut :

1. Topsis dimulai dengan membangun sebuah matriks keputusan Matriks keputusan X mengacu terhadap m alternatif yang akan dievaluasi berdasarkan $\mathrm{n}$ kriteria.

$$
x=\left\{\begin{array}{c}
A_{1} X_{11} X_{12} X_{13} \ldots . X_{1 n} \\
A_{2} X_{21} X_{22} X_{33} \ldots . X_{2 n} \\
A_{3} X_{31} X_{32} X_{33} \ldots . X_{3 n} \\
A_{m} X_{m 1} X_{m 2} X_{m 3} \ldots . X_{m n}
\end{array}\right\}
$$

Dimana Ai $(i=1,2,3, \ldots . . m)$ adalah alternative yang mungkin, $\mathrm{Xj}(\mathrm{j}=1,2,3, \ldots \mathrm{n})$ adalah atribut dimana performansi alternative diukur, Xij adalah performansi alternative Ai dengan acuan atribut Xj.

2. Membuat matriks keputusan yang ternormalisasi

$$
r i j=\sqrt{\sum_{i}^{m} \frac{x i j}{\sqrt{\sum_{m=1}^{m} x_{i j}^{2}}}}
$$

dengan $i=1,2, \ldots, m$

$$
j=1,2 \ldots, n
$$

Dimana :

$$
\begin{aligned}
& \mathrm{r}_{\mathrm{ij}}=\text { matrik ternormalisasi }[\mathrm{i}][\mathrm{j}] \\
& \mathrm{x}_{\mathrm{ij}}=\text { matrik keputusan }[\mathrm{i}][\mathrm{j}]
\end{aligned}
$$

3. Membuat matriks keputusan ternormalisasi terbobot

$$
\begin{aligned}
& \text { Vij }=\text { wirij } ; \\
& \text { dengan } i=1,2, \ldots, m ; \text { dan } j=1,2, \ldots, n \text {. }
\end{aligned}
$$


Dimana :

$$
\begin{array}{ll}
\mathrm{V}_{\mathrm{ij}}= & \begin{array}{l}
\text { Elemen dari matriks keputusan } \\
\text { yang ternormalisasi terbobot }
\end{array} \\
\mathrm{V}_{\mathrm{wi}}=\quad \begin{array}{l}
\text { Bobot dari kriteria ke- } \mathrm{j} \\
\mathrm{r}_{\mathrm{ij}}=\quad \begin{array}{l}
\text { Elemen matriks keputusan yang } \\
\text { ternormalisasi } \mathrm{R}
\end{array}
\end{array}
\end{array}
$$

4. Solusi ideal positif A+ dan solusi ideal negative Adapat ditentukan berdasarkan rating bobot ternormalisasi (yij) sebagai:

$$
\begin{aligned}
& A^{+}=\left(y_{1}^{+}, y_{2}^{+}, \ldots, y_{n}^{+}\right) \\
& A^{-}=\left(y_{1}^{-}, y_{2}^{-}, \ldots, y_{n}^{-}\right)
\end{aligned}
$$

Dimana :

$\mathrm{V}_{\mathrm{j}}^{+}=\max \mathrm{Y}_{\text {if }}$ jika $j$ adalah atribut

Keuntungan

Min $Y_{\text {ij }}$ jika $j$ adalah atribut biaya

$\mathrm{V}_{\mathrm{j}}^{-}=$min yij, jika $\mathrm{j}$ adalah atribut Keuntungan

Max yij, jika $j$ adalah atribut biaya

5. Jarak antara alternative Ai dengan solusi ideal positif :

$$
D_{i}^{+}=\sqrt{\sum_{i-1}^{n}\left(V_{i j}-V_{i}\right)^{2}}
$$

Dimana :

$$
\begin{aligned}
\mathrm{D}_{\mathrm{i}}^{+}= & \begin{array}{l}
\text { Jarak alternative Ai dengan solusi } \\
\text { ideal positif }
\end{array} \\
\mathrm{Y}_{\mathrm{j}}^{+}= & \text {Solusi ideal positif }[\mathrm{i}] \\
\mathrm{Y}_{\mathrm{ij}}= & \text { matriks normalisasi }[\mathrm{i}][\mathrm{j}]
\end{aligned}
$$

6. Jarak antara alternative Ai dengan solusi ideal negative

$$
\begin{aligned}
& D_{i}^{+}=\sqrt{\sum_{i-1}^{n}\left(V_{i j}-V_{i}\right)^{2}} \\
& \mathrm{i}=1,2, \ldots \mathrm{m}
\end{aligned}
$$

Dimana :

$$
\begin{aligned}
\mathrm{D}_{\mathrm{i}^{-}}= & \begin{array}{l}
\text { Jarak alternative Ai dengan solusi } \\
\text { ideal negative }
\end{array} \\
\mathrm{Y}_{\mathrm{j}^{-}}= & \text {Solusi ideal negatif }[\mathrm{i}] \\
\mathrm{Y}_{\mathrm{ij}}= & \text { matriks normalisasi }[\mathrm{i}][\mathrm{j}]
\end{aligned}
$$

7. Nilai preferensi untuk setiap alternative (Vi) diberikan sebagai

$$
\begin{aligned}
& V_{i}=\frac{D_{i}^{-}}{D_{i}^{-}+D_{i}^{+}} \\
& \mathrm{i}=1,2, \ldots \mathrm{m}
\end{aligned}
$$

Dimana :

$$
\begin{array}{ll}
\mathrm{V}_{\mathrm{i}}= & \begin{array}{l}
\text { kedekatan tiap alternative } \\
\text { terhadap solusi ideal }
\end{array} \\
\mathrm{D}_{\mathrm{i}}^{+}=\quad \begin{array}{l}
\text { Jarak alternative Ai dengan solusi } \\
\text { ideal positif }
\end{array} \\
\mathrm{D}_{\mathrm{i}}^{-}=\quad \begin{array}{l}
\text { Jarak alternative Ai dengan solusi } \\
\text { ideal negative }
\end{array}
\end{array}
$$

Nilai $V_{i}$ yang lebih besar menunjukkan bahwa alternatif $A_{i}$ lebih dipilih

\section{Tanaman Bonsai}

Bonsai merupakan salah satu seni pemangkasan tanaman (pohon) agar tumbuh kerdil, mini atau cebol. Untuk memperoleh kesempurnaan membutuhkan waktu yang relatif lama. Selain itu, juga membutuhkan kreativitas, kesabaran, ketekunan, dan kecintaan pembuatan terhadap tanaman. Istilah bonsai berasal dari kata bon yang berarti pot dan sai yang berarti tanaman. Dengan demikian bonsai bisa diartikan sebagai tanaman yang dikerdilkan dan ditanam dalam pot[1].

Menurut Stephen Orr (di The New York Times), Bonsai adalah tanaman yang ditanam dalam wadah dangkal mengikuti prinsip pemangkasan dan pelatihan bonsai yang tepat, menghasilkan replika miniatur berseni dari pohon dewasa di alam[5].

Menurut Kamus Besar Bahasa Indonesia (KBBI), Bonsai adalah tumbuhan kerdil, diperoleh dengan menanamnya dalam pot dengan cara tertentu (pot dangkal, pemangkasan akar dan cabang, pemupukan terkendali, dan sebagainya) tanaman yang dikerdilkan[6].

Ukuran Tanaman Bonsai ada banyak ragamnya mulai dari yang kecil sampai yang besar itu tergantung dari masing-masing individu yang membuat nya. Bonsai dikelompokkan menjadi lima kelompok berdasarkan tinggi tanaman dari pangkal batang hingga bagian puncak tanaman[1].

\section{Sangat Besar}

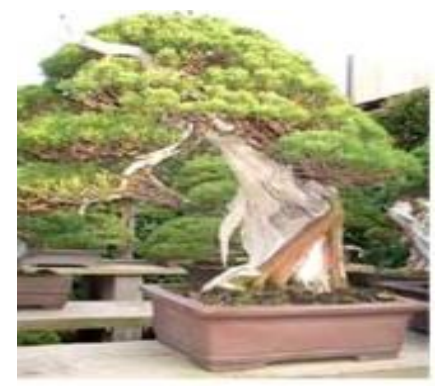

Gambar 1. Bonsai Sangat Besar

Bonsai berukuran sangat besar memiliki ukuran $90-150$ $\mathrm{cm}$. Bonsai ini hanya cocok di letakkan di tanaman[1].

2. Besar 


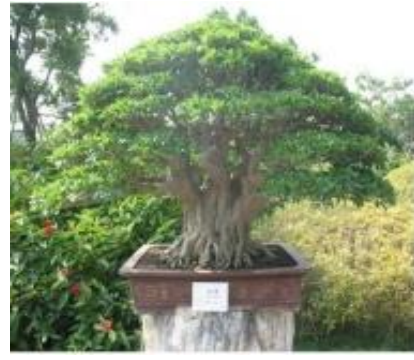

Gambar 2. Bonsai Besar

Bonsai berukuran besar disebut juga dengan dai bonsai yang berukuran $60-90 \mathrm{~cm}$. Bonsai ini tidak mudah dipindah-pindahkan karena ukuran pot nya cukup besar dan berat. Biasanya bonsai jenis ini ditempatkan di teras atau di kebun taman[1].

3. Sedang

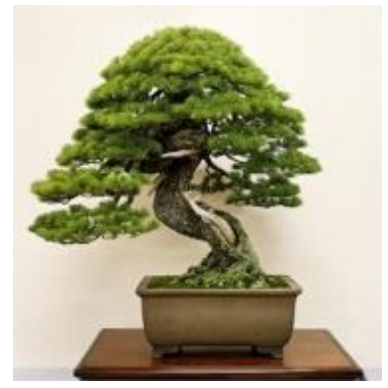

Gambar 3. Bonsai Sedang

Bonsai berukuran sedang disebut juga dengan chiu bonsai yang berukuran $30-60 \mathrm{~cm}$. Jenis bonsai ini mudah ditangani. Perbandingan tinggi tanaman dengan pot adalah 3 : 1. Biasanya bonsai ini diletakkan di sudut ruangan yang cukup mendapat cahaya matahari.[1]

4. Kecil

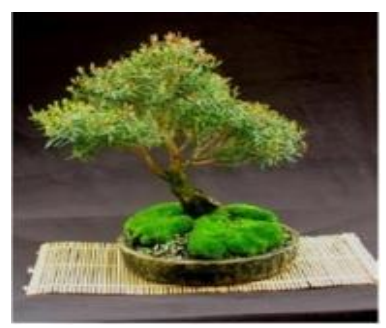

Gambar 4. Bonsai Kecil

Bonsai berukuran kecil disebut juga dengan ko bonsai yang berukuran $15-30 \mathrm{~cm}$. Jenis bonsai ini banyak digemari oleh masyarakat di Indonesia. Bonsai kelompok ini tingginya mencapai tiga kali tinggi pot[1].

5. Sangat Kecil

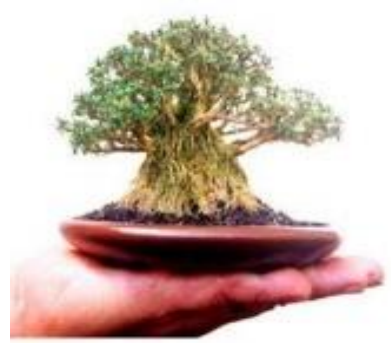

Gambar 5. Bonsai Sangat Kecil

Bonsai berukuran sangat kecil disebut dengan mame bonsai. Bonsai sangat kecil berukuran $5-15 \mathrm{~cm}$. Bonsai mini dengan pot yang sangat kecil sekarang mulai populer karena dapat dipajang di atas meja tamu[1].

\section{Metodologi}

Sample yang digunakan dalam pemilihan tanaman bonsai terbaik dengan metode TOPSIS menggunakan lima (5) alternatif dan enam (6) kriteria. Prosedur perhitungan yang dilakukan adalah :

Menentukan nilai relatif terhadap masing-masing alternatif. Dalam prosesnya memerlukan kriteria yang akan dijadikan bahan pertimbangan pada proses perangkingan. Kriteria yang menjadi bahan pertimbangan pada pemilihan tanaman bonsai terbaik seperti yang ditunjukkan pada beberapa penyelesaian dibawah ini:

Tabel 1 Kriteria

\begin{tabular}{ll}
\hline Keterangan & Kriteria \\
\hline Usia Tanaman & C1 \\
Tinggi Tanaman & C2 \\
Jenis Batang & C3 \\
Kondisi Daun & C4 \\
Ukuran Daun & C5 \\
Jumlah Daun & C6 \\
\hline
\end{tabular}

Menentukan rangking setiap alternatif pada setiap kriteria dinilai dengan 1 sampai 5.

Tabel 2. Bobot Nilai

\begin{tabular}{ll}
\hline Bobot & Nilai \\
\hline Sangat Buruk & 1 \\
Buruk & 2 \\
Cukup Baik & 3 \\
Baik & 4 \\
Sangat Baik & 5 \\
\hline
\end{tabular}

Pada matriks keputusan, kolom matriks menyatakan atribut yaitu kriteria-kriteria yang ada, sedangkan baris matriks menyatakan alternatif yaitu nama tanaman bonsai yang akan dibandingkan dan tipe kriteria adalah benefit. Matriks keputusan dapat dilihat pada tabel di bawah ini.

Tabel 3 Usia Tanaman (C1)

\begin{tabular}{ccl}
\hline No & Kriteria Usia & Bobot \\
\hline 1 & $>=20$ Tahun & 5 \\
2 & $>=10$ Tahun & 4
\end{tabular}




\begin{tabular}{lll}
3 & $>=5$ Tahun & 3 \\
4 & $<=4$ Tahun & 2 \\
\hline
\end{tabular}

Tabel 4 Tinggi Tanaman (C2)

\begin{tabular}{cll}
\hline No & Kriteria Tinggi & Bobot \\
\hline 1 & $<=9 \mathrm{~cm}$ & 5 \\
2 & $>=10 \mathrm{~cm}$ & 4 \\
3 & $>=30 \mathrm{~cm}$ & 3 \\
4 & $>=70 \mathrm{~cm}$ & 2 \\
5 & $>=100 \mathrm{~cm}$ & 1 \\
\hline
\end{tabular}

Tabel 5 Jenis Batang (C3)

\begin{tabular}{cll}
\hline No & Kriteria Batang & Bobot \\
\hline 1 & Keras & 5 \\
2 & Lunak & 4 \\
\hline
\end{tabular}

Tabel 6 Kondisi Daun (C4)

\begin{tabular}{cll}
\hline No & Kriteria Batang & Bobot \\
\hline 1 & Segar Hijau & 5 \\
2 & Segar Hijau Kekuningan & 4 \\
3 & Tidak Segar & 3 \\
4 & Terdapat Hama & 1 \\
\hline
\end{tabular}

Tabel 7 Ukuran Daun (C5)

\begin{tabular}{cll}
\hline No & Kriteria Batang & Bobot \\
\hline 1 & $<=10 \mathrm{~mm}$ & 5 \\
2 & $>=20 \mathrm{~mm}$ & 4 \\
3 & $>=40 \mathrm{~mm}$ & 3 \\
4 & $>=70 \mathrm{~mm}$ & 2 \\
\hline
\end{tabular}

Tabel 8 Jumlah Daun (C6)

\begin{tabular}{lll}
\hline No & Kriteria Batang & Bobot \\
\hline 1 & Banyak & 5 \\
2 & Sedang & 4 \\
3 & Sedikit & 3 \\
4 & Tidak Ada & 2 \\
\hline
\end{tabular}

Dari beberapa kriteria yang ada diatas, maka dilakukan sampel dalam pembobotan yang dimana tanaman bonsai dilibatkan dalam membuat suatu matriks keputusan.

Tabel 9 Matriks Keputusan

\begin{tabular}{ccccccc}
\hline Alternatif & C1 & C2 & C3 & C4 & C5 & C6 \\
\hline A1 & 2 & 4 & 5 & 5 & 4 & 4 \\
A2 & 4 & 1 & 5 & 5 & 3 & 5 \\
A3 & 4 & 3 & 5 & 4 & 4 & 4 \\
A4 & 2 & 3 & 5 & 5 & 3 & 5 \\
A5 & 1 & 3 & 4 & 4 & 3 & 5 \\
\hline
\end{tabular}

Keterangan Alternatif :

A1 Bonsai Beringin Dolar

A2 Bonsai Serut

\begin{tabular}{ll}
\hline A3 & Bonsai Kemuning \\
A4 & Bonsai Beringin Kimeng \\
A5 & Bonsai Adinium \\
\hline
\end{tabular}

\begin{tabular}{ll}
\hline & \multicolumn{1}{c}{ Keterangan Kriteria : } \\
\hline C1 & Usia Tanaman \\
C2 & Tinggi Tanaman \\
C3 & Jenis Batang \\
C4 & Kondisi Daun \\
C5 & Ukuran Daun \\
C6 & Jumlah Daun \\
\hline
\end{tabular}

Tabel 10 Menentukan bobot kriteria

\begin{tabular}{lcc}
\hline \multicolumn{1}{c}{ Kriteria } & Range (\%) & Bobot \\
\hline Usia Tanaman & 25 & 0.25 \\
Tinggi Tanaman & 30 & 0.3 \\
Jenis Batang & 20 & 0.2 \\
Kondisi Daun & 10 & 0.1 \\
Ukuran Daun & 10 & 0.1 \\
Jumlah Daun & 5 & 0.05 \\
\hline
\end{tabular}

\section{Hasil dan Pembahasan}

\section{A. Perancangan Topsis}

Adapun pembahasan dari penelitian ini sebagai berikut: 1. Membuat Matriks keputusan yang ternormalisasi setelah matrik keputusan dibangun, selanjutnya adalah membuat matriks keputusan ternormalisasi $\mathrm{R}$ yang elemenelemennya ditentukan dengan rumus persamaan :

$$
r i j=\sqrt{\sum_{i}^{m} \frac{x i j}{\sqrt{\sum_{m=1}^{m} x_{i j}^{2}}}}
$$

Dimana :

$\mathrm{r}_{\mathrm{ij}}$ adalah elemen dari matrik keputusan yang ternormalisasi $\mathrm{R}$

$\mathrm{x}_{\mathrm{ij}}$ adalah elemen dari matriks keputusan,

$\mathrm{I}=1,2,3, \ldots \mathrm{m}$,

$\mathrm{j}=1,2,3, \ldots \mathrm{m}$,

Matriks keputusan ternormalisasi dapat dilihat pada penyelesaian berikut :

$$
\begin{gathered}
r_{11}=\frac{r_{11}}{\sqrt{x_{11}+x_{21}+x_{31}+x_{41}+x_{51}+x_{61}}} \\
\left|X_{1}\right|=\sqrt{2^{2}+4^{2}+5^{2}+5^{2}+4^{2}+4^{2}} \\
=\sqrt{9+9+25+25+16+16} \\
=\sqrt{102}=10.099
\end{gathered}
$$




$$
\begin{aligned}
& r_{11}=\frac{x_{11}}{x_{1}}=\frac{2}{10.099}=0.1980 \\
& r_{21}=\frac{x_{21}}{x_{1}}=\frac{4}{10.099}=0.3960 \\
& r_{31}=\frac{x_{31}}{x_{1}}=\frac{5}{10.099}=0.4950 \\
& r_{41}=\frac{x_{41}}{x_{1}}=\frac{5}{10.099}=0.4950 \\
& r_{51}=\frac{x_{51}}{x_{1}}=\frac{4}{10.099}=0.3960 \\
& r_{61}=\frac{x_{16}}{x_{1}}=\frac{4}{10.099}=0.3960
\end{aligned}
$$

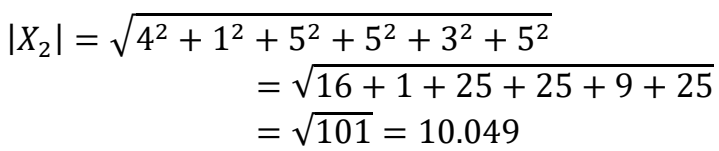$$
r_{12}=\frac{x_{12}}{x_{2}}=\frac{4}{10.0498}=0.3980
$$$$
r_{22}=\frac{x_{22}}{x_{2}}=\frac{1}{10.0498}=0.0995
$$$$
r_{32}=\frac{x_{32}}{x_{2}}=\frac{5}{10.0498}=0.4975
$$$$
r_{42}=\frac{x_{42}}{x_{2}}=\frac{5}{10.0498}=0.4975
$$$$
r_{52}=\frac{x_{52}}{x_{2}}=\frac{3}{10.0498}=0.2985
$$$$
r_{62}=\frac{x_{62}}{x_{2}}=\frac{5}{10.0498}=0.4975
$$

$$
\begin{aligned}
& \left|X_{3}\right|=\sqrt{4^{2}+3^{2}+5^{2}+4^{2}+4^{2}+4^{2}} \\
& =\sqrt{16+9+25+16+16+16} \\
& =\sqrt{98}=9.8994
\end{aligned}
$$

$$
r_{13}=\frac{x_{13}}{x_{3}}=\frac{4}{9.8994}=0.4040
$$$$
r_{23}=\frac{x_{23}}{x_{3}}=\frac{3}{9.8994}=0.3030
$$$$
r_{33}=\frac{x_{33}}{x_{3}}=\frac{5}{9.8994}=0.5050
$$$$
r_{43}=\frac{x_{43}}{x_{3}}=\frac{4}{9.8994}=0.4040
$$$$
r_{53}=\frac{x_{53}}{x_{3}}=\frac{4}{9.8994}=0.4040
$$$$
r_{63}=\frac{x_{63}}{x_{3}}=\frac{4}{9.8994}=0.4040
$$

$$
\begin{aligned}
\left|X_{4}\right|=\sqrt{2^{2}+3^{2}} & +5^{2}+5+3^{2}+5^{2} \\
& =\sqrt{4+9+25+25+9+25} \\
& =\sqrt{97}=9.8488
\end{aligned}
$$

$$
r_{14}=\frac{x_{14}}{x_{4}}=\frac{2}{9.8444}=0.2030
$$$$
r_{24}=\frac{x_{24}}{x_{4}}=\frac{3}{9.8444}=0.3046
$$$$
r_{34}=\frac{x_{34}}{x_{4}}=\frac{5}{9.8444}=0.5076
$$$$
r_{44}=\frac{x_{44}}{x_{4}}=\frac{5}{9.8444}=0.5076
$$$$
r_{54}=\frac{x_{54}}{x_{4}}=\frac{3}{9.8444}=0.3046
$$ 


$$
r_{64}=\frac{x_{64}}{x_{4}}=\frac{5}{9.8444}=0.5076
$$

$$
\begin{aligned}
& \left|X_{5}\right|=\sqrt{1^{2}+3^{2}+4^{2}+4^{2}+3^{2}+5^{2}} \\
& =\sqrt{1+9+16+16+9+25} \\
& =\sqrt{76}=8.7177
\end{aligned}
$$$$
r_{15}=\frac{x_{15}}{x_{5}}=\frac{1}{8.7177}=0.1147
$$$$
r_{25}=\frac{x_{25}}{x_{5}}=\frac{3}{8.7177}=0.3441
$$$$
r_{35}=\frac{x_{35}}{x_{5}}=\frac{4}{8.7177}=0.4588
$$$$
r_{45}=\frac{x_{45}}{x_{5}}=\frac{4}{8.7177}=0.4588
$$$$
r_{55}=\frac{x_{55}}{x_{5}}=\frac{3}{8.7177}=0.3441
$$$$
r_{65}=\frac{x_{65}}{x_{5}}=\frac{5}{8.7177}=0.5735
$$

Sehingga diperoleh hasil perhitungan matriks keputusan ternormalisasi sebagai berikut :

Tabel 11 Hasil perhitungan matriks

\begin{tabular}{ccccc}
\hline $\mathbf{X}_{\mathbf{1}}$ & $\mathbf{X}_{\mathbf{2}}$ & $\mathbf{X}_{\mathbf{3}}$ & $\mathbf{X}_{\mathbf{4}}$ & $\mathbf{X}_{\mathbf{5}}$ \\
\hline 0.1980 & 0.3980 & 0.4040 & 0.2030 & 0.1147 \\
0.3960 & 0.0995 & 0.3030 & 0.3046 & 0.3441 \\
0.4950 & 0.4975 & 0.5050 & 0.5076 & 0.4588 \\
0.4950 & 0.4975 & 0.4040 & 0.5076 & 0.4588 \\
0.3960 & 0.2985 & 0.4040 & 0.3046 & 0.3441 \\
0.3960 & 0.4975 & 0.4040 & 0.5076 & 0.5735 \\
\hline
\end{tabular}

2. Membuat matriks keputusan yang ternomalisasi terbobot $\mathrm{V}$.

Digunakan rumus :

$\mathrm{V}_{\mathrm{ij}}=\mathrm{W}_{\mathrm{i}} * \mathrm{R}_{\mathrm{ij}}$

Dimana :

Ij $\mathrm{v}$ adalah elemen dari matriks keputusan yang ternormalisasi terbobot v. Bobot ij w (w1,w2,w3,..,wn) adalah bobot dari kriteria j
Ij r adalah elemen dari matriks keputusan yang ternormalisasi $\mathrm{R}$

Dengan $\mathrm{i}=1,2,3, \ldots, \mathrm{m}$; dan $\mathrm{J}=1,2,3, \ldots, \mathrm{n}$ Matriks keputusan ternormalisasi terbobot dapat dilihat dengan penyelesaian berikut :

$\mathrm{V}_{11}=\mathrm{W}_{1} * \mathrm{R}_{11}=0.25 * 0.1980=0.0495$

$\mathrm{V}_{21}=\mathrm{W}_{1} * \mathrm{R}_{21}=0.25 * 0.3980=0.0995$

$\mathrm{V}_{31}=\mathrm{W}_{1} * \mathrm{R}_{31}=0.25 * 0.4040=0.101$

$\mathrm{V}_{41}=\mathrm{W}_{1} * \mathrm{R}_{41}=0.25 * 0.2030=0.0507$

$\mathrm{V}_{51}=\mathrm{W}_{1} * \mathrm{R}_{51}=0.25 * 0.1147=0.0286$

$\mathrm{V}_{12}=\mathrm{W}_{2} * \mathrm{R}_{12}=0.3 * 0.3960=0.1188$

$\mathrm{V}_{22}=\mathrm{W}_{2} * \mathrm{R}_{22}=0.3 * 0.0995=0.0298$

$\mathrm{V}_{32}=\mathrm{W}_{2} * \mathrm{R}_{32}=0.3 * 0.3030=0.0909$

$\mathrm{V}_{42}=\mathrm{W}_{2} * \mathrm{R}_{42}=0.3 * 0.3046=0.0913$

$\mathrm{V}_{52}=\mathrm{W}_{2} * \mathrm{R}_{52}=0.3 * 0.3441=0.1032$

$\mathrm{V}_{13}=\mathrm{W}_{3} * \mathrm{R}_{13}=0.2 * 0.4950=0.099$

$\mathrm{V}_{23}=\mathrm{W}_{3} * \mathrm{R}_{23}=0.2 * 0.4975=0.0995$

$\mathrm{V}_{33}=\mathrm{W}_{3} * \mathrm{R}_{33}=0.2 * 0.5050=0.101$

$\mathrm{V}_{43}=\mathrm{W}_{3} * \mathrm{R}_{43}=0.2 * 0.5076=0.1015$

$\mathrm{V}_{53}=\mathrm{W}_{3} * \mathrm{R}_{53}=0.2 * 0.4588=0.0917$

$\mathrm{V}_{14}=\mathrm{W}_{4} * \mathrm{R}_{14}=0.1 * 0.4950=0.0495$

$\mathrm{V}_{24}=\mathrm{W}_{4} * \mathrm{R}_{24}=0.1 * 0.4975=0.0497$

$\mathrm{V}_{34}=\mathrm{W}_{4} * \mathrm{R}_{34}=0.1 * 0.4040=0.0404$

$\mathrm{V}_{44}=\mathrm{W}_{4} * \mathrm{R}_{44}=0.1 * 0.5076=0.0507$

$\mathrm{V}_{54}=\mathrm{W}_{4} * \mathrm{R}_{54}=0.1 * 0.4930=0.0458$

$\mathrm{V}_{15}=\mathrm{W}_{5} * \mathrm{R}_{15}=0.1 * 0.3960=0.0396$

$\mathrm{V}_{25}=\mathrm{W}_{5} * \mathrm{R}_{25}=0.1 * 0.2985=0.0298$

$\mathrm{V}_{35}=\mathrm{W}_{5} * \mathrm{R}_{35}=0.1 * 0.4040=0.0404$

$\mathrm{V}_{45}=\mathrm{W}_{5} * \mathrm{R}_{45}=0.1 * 0.3046=0.0304$

$\mathrm{V}_{55}=\mathrm{W}_{5} * \mathrm{R}_{55}=0.1 * 0.3441=0.0344$

$\mathrm{V}_{16}=\mathrm{W}_{6} * \mathrm{R}_{16}=0.05 * 0.3960=0.0198$

$\mathrm{V}_{26}=\mathrm{W}_{6} * \mathrm{R}_{26}=0.05 * 0.4975=0.0248$

$\mathrm{V}_{36}=\mathrm{W}_{6} * \mathrm{R}_{36}=0.05 * 0.4040=0.0202$

$\mathrm{V}_{46}=\mathrm{W}_{6} * \mathrm{R}_{46}=0.05 * 0.5076=0.0253$

\begin{tabular}{|c|c|c|c|c|c|c|}
\hline & $\begin{array}{l}0.049 \\
5\end{array}$ & $\begin{array}{l}0.118 \\
8\end{array}$ & 0.099 & $\begin{array}{l}0.049 \\
5\end{array}$ & $\begin{array}{l}0.039 \\
6\end{array}$ & $\begin{array}{l}0.019 \\
8\end{array}$ \\
\hline & 0.099 & 0.029 & 0.099 & 0.049 & 0.029 & 0.024 \\
\hline & 5 & 8 & 5 & 7 & 8 & 8 \\
\hline $\mathrm{R}$ & 0.101 & 0.090 & 0.101 & 0.040 & 0.040 & 0.020 \\
\hline$=$ & & 9 & & 4 & 4 & 2 \\
\hline & 0.050 & 0.091 & 0.101 & 0.050 & 0.030 & 0.025 \\
\hline & 7 & 3 & 5 & 7 & 4 & 3 \\
\hline & 0.029 & 0.103 & 0.091 & 0.045 & 0.034 & 0.028 \\
\hline & 8 & 2 & 7 & 8 & 4 & 6 \\
\hline
\end{tabular}

$\mathrm{V}_{56}=\mathrm{W}_{6} * \mathrm{R}_{56}=0.05 * 0.5735=0.0298$

Sehingga diperoleh hasil perhitungan keputusan ternormalisasi terbobot berikut :

Selanjutnya menentukan matriks solusi ideal positif $\left(\mathrm{A}^{+}\right)$ dan ideal negatif $\left(\mathrm{A}^{-}\right)$ 
Tabel 12 Solusi ideal positif

\begin{tabular}{ccccccc}
\hline $\begin{array}{c}\mathrm{A} \\
+\end{array}$ & $\mathrm{C} 1$ & $\mathrm{C} 2$ & $\mathrm{C} 3$ & $\mathrm{C} 4$ & $\mathrm{C} 5$ & $\mathrm{C} 6$ \\
\hline & 0.10 & 0.118 & 0.101 & 0.050 & 0.040 & 0.028 \\
1 & 8 & 5 & 7 & 4 & 6 \\
\hline
\end{tabular}

Tabel 13 Solusi ideal negative

\begin{tabular}{ccccccc}
\hline $\mathrm{A}$ & $\mathrm{C} 1$ & $\mathrm{C} 2$ & $\mathrm{C} 3$ & $\mathrm{C} 4$ & $\mathrm{C} 5$ & $\mathrm{C} 6$ \\
\hline & 0.028 & 0.029 & 0.091 & 0.040 & 0.029 & 0.019 \\
6 & 8 & 7 & 4 & 8 & 8 \\
\hline
\end{tabular}

3. Menghitung jarak alternative dari solusi ideal positif (D+) dan ideal negatif (D-).

Alternatif dari ideal positif menggunakan Rumus :

$$
D_{i}^{+}=\sqrt{\sum_{i-1}^{n}\left(V_{i j}-V_{i}\right)^{2}}
$$

Menghitung jarak alternatif terbobot dengan solusi ideal positif $\left(\mathrm{D}_{\mathrm{i}}^{+}\right)$

$$
\begin{aligned}
\sqrt{(0.1980-0.101)^{2}+}(0.3960-0.1188)^{2} \\
+(0.4950-0.1015)^{2} \\
+(0.4950-0.0507)^{2} \\
+(0.3960-0.0404)^{2} \\
+(0.3960-0.0286)^{2} \\
=\sqrt{0.00273802} \\
=0.05232609
\end{aligned}
$$

Dan seterusnya

Tabel 14 Perhitungan separasi positif

\begin{tabular}{ll}
\hline Alternatif & R \\
\hline Bonsai Beringin Dolar & 0.05232609 \\
Bonsai Serut & 0.08974993 \\
Bonsai Kemuning & 0.03090808 \\
Bonsai Beringin Kimeng & 0.05828576 \\
Bonsai Adinium & 0.07510772 \\
\hline
\end{tabular}

Menghitung jarak alternatif terbobot dengan solusi ideal negative $\left(\mathrm{D}_{\mathrm{i}^{-}}\right)$

$$
\begin{aligned}
& \sqrt{(0.1980-0.0286)^{2}+}(0.3960 \\
&-0.0298)^{2} \\
&+(0.4950-0.0917)^{2} \\
&+(0.4950-0.0404)^{2} \\
&+(0.3960-0.0298)^{2} \\
&+(0.3960-0.0198)^{2} \\
&=\sqrt{0.00858995} \\
&=0.09268198
\end{aligned}
$$

Dan seterusnya

Tabel 15 Perhitungan separasi negatif

\begin{tabular}{ll}
\hline Alternatif & R \\
\hline
\end{tabular}

\begin{tabular}{ll}
\hline Bonsai Beringin Dolar & 0.09268198 \\
Bonsai Serut & 0.07210506 \\
Bonsai Kemuning & 0.09578098 \\
Bonsai Beringin Kimeng & 0.06710737 \\
Bonsai Adinium & 0.07426520 \\
\hline
\end{tabular}

4. Setelah menghitung separatif negatif alternatif dari solusi ideal positif $\left(\mathrm{A}^{+}\right)$dan ideal positif $\left(\mathrm{A}^{-}\right)$, selanjutnya adalah menghitung kedekatan relatif terhadap solusi ideal positif.

$V_{i}=\frac{D_{i}^{-}}{D_{i}^{-}+D_{i}^{+}}$

$$
\begin{gathered}
V_{1}=\frac{0.09268198}{0.09268198+0.05232609} \\
=0.639150 \\
V_{2}=\frac{0.07210506}{0.07210506+0.08974993} \\
=0.590404
\end{gathered}
$$

5. Selanjutnya alternative diurutkan dari nilai $\mathrm{C}^{+}$terbesar ke nilai $\mathrm{C}^{+}$terkecil. Alternatif dengan nilai $\mathrm{C}^{+}$terbesar merupakan solusi yang terbaik.

Tabel 16 Pengurutan alternative

\begin{tabular}{cll}
\hline Simbol & Alternatif & Nilai \\
\hline A3 & Bonsai Kemuning & 0.756031 \\
A1 & Bonsai Beringin Dolar & 0.639150 \\
A4 & Bonsai Beringin Kimeng & 0.535175 \\
A5 & Bonsai Adinium & 0.497179 \\
A2 & Bonsai Serut & 0.445491 \\
\hline
\end{tabular}

Dapat dilihat pada tabel di atas yang menempati urutan pertama yaitu A3 (Bonsai Kemuning) dengan nilai 
0.756031, alternative yang menempati urutan kedua yaitu A1 (Bonsai Beringin Dolar) dengan nilai 0.639150, alternatif yang menempati urutan ketiga yaitu A5 (Bonsai Beringin Kimeng) dengan nilai 0.535175 , alternatif yang menempati urutan keempat yaitu A5 (Bonsai Adinium) dengan nilai 0.497179 , dan yang menempati urutan kelima yaitu A2 (Bonsai Serut) dengan nilai 0.445491. Berdasarkan hasil pengurutan, maka pilihan terbaik adalah alternatif A3 yaitu Bonsai Kemuning karena memenuhi kriteria-kriteria yang ditentukan dan dapat dianjurkan untuk pemilihan bonsai terbaik.

\section{B. Implementasi}

Implementasi berfungsi untuk menampilkan antar muka dalam sistem pengambilan keputusan. dengan implementasi ini, maka pengaplikasian sistem pendukung keputusan akan lebih mudah penggunaannya dan lebih tepat hasilnya. Hasil dari implementasi dapat dilihat pada gambar berikut.

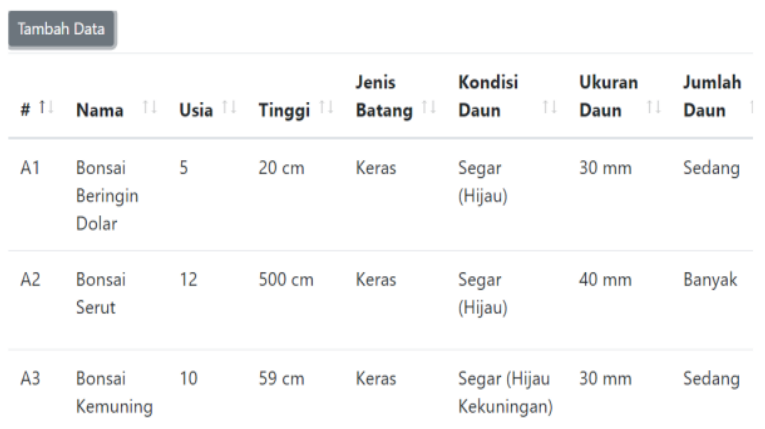

Gambar 6. Halaman pengelola alternative

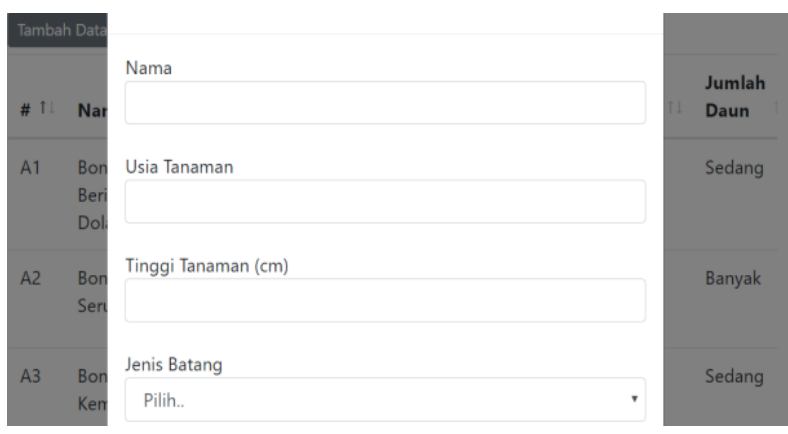

Gambar 7. Input data alternative

\begin{tabular}{llll} 
Kode & Nama & Bobot & Aksi \\
\hline C1 & Usia Tanaman & 25 & \\
C2 & Tinggi Tanaman & 30 & \\
C3 & Jenis Batang & 20 & \\
C4 & Kondisi Daun & 10 \\
C5 & Ukuran Daun & 10 & \\
C6 & Jumlah Daun & 5
\end{tabular}

Gambar 8. Halaman pengelola kriteria

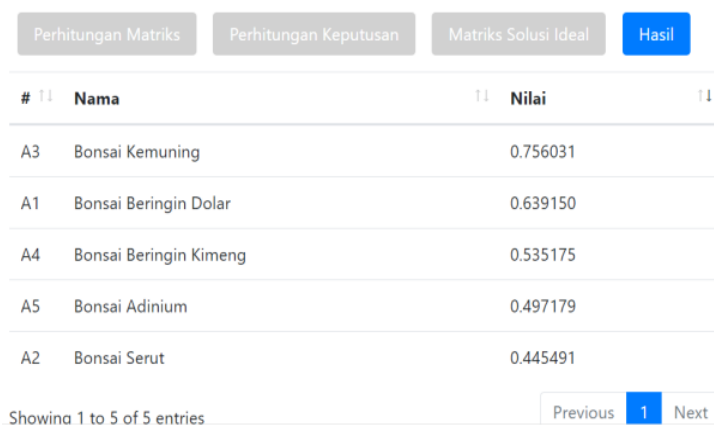

Gambar 9 Halaman proses dan hasil.

\section{Kesimpulan}

Berdasarkan hasil penelitian dan analisa dapat disimpulkan bahwa dengan penerapan metode Technique for Others Reference by Similarity to Ideal Solution (TOPSIS) mampu memberikan perhitungan perankingan dan memberikan solusi bagi masyarakat yang ingin memiliki tanaman bonsai terbaik berdasarkan enam (6) kriteria yaitu usia tanaman, tinggi tanaman, jenis batang, kondisi daun, ukuran daun, dan jumlah daun, dengan lima (5) alternatif.

\section{Daftar Pustaka}

[1] S. Dwilestari and S. Nurmiati, "Sistem Pakar Penentuan Style Pada Tanaman Bonsai Menggunakan Metode Certainty Factor," vol. 28, no. 2, pp. 49-56, 2018.

[2] D. Kurniawan and S. Ipnuwati, "Penggunaan Metode Topsis Menentukan Jenis Bambu Untuk Pembuatan Alat Rumah Tangga 'Tradisional,"' J. Chem. Inf. Model., vol. 53, no. 9, pp. 1689-1699, 2013, doi: 10.1017/CBO9781107415324.004.

[3] E. Aprilia and S. Ipnuwati, "Sistem Pendukung Keputusan Pemilihan Wisata Air Terjun Unggulan Dengan Menggunakan Metode Topsis Di Kabupaten Pesawaran," STMIK Pringsewu Lampung, pp. 53-61.

[4] Ratnasari and T. Susilowati, "Sistem Pendukung Keputusan Kelayakan Pengajuan Kredit Sepeda Motor pada Dealer Tunas Dwipa Matra Gadingrejo Menggunakan Metode SAW," STMIK Pringsewn Lampung, pp. 442-448, 2016.

[5] S. Orr, "Not All Trees Are Cut Out to Be Bonsai." [Online]. Available: https://www.nytimes.com/2009/02/26/garden/2 Gqna.html.

[6] "KBBI Kemdikbud." [Online]. Available: https://kbbi.kemdikbud.go.id/entri/bonsai. 